Archive for

Organic Chemistry

Arkivoc 2020, part vii, 16-26

\title{
The Hemetsberger reaction: A new approach to the synthesis of novel dihydroindoloindole systems
}

\author{
Murat Bingul, ${ }^{a, b}$ Naresh Kumar, ${ }^{a}$ and David StC Black*a \\ ${ }^{a}$ School of Chemistry, The University of New South Wales, Sydney, NSW 2052, Australia \\ ${ }^{b}$ School of Pharmacy, Dicle University, Diyarbakır 21280, Turkey
}

Email: d.black@unsw.edu.au

\section{Dedicated to Professor Jan Bergman on the occasion of his $80^{\text {th }}$ birthday}

Received 02-27-2020

Accepted 04-28-2020

Published on line 05-05-2020

\section{Abstract}

The Hemetsberger indole synthesis provides an alternative method for the preparation of dihydroindoloindole systems. Two novel examples, dimethyl 3,8-dihydroindolo[7,6-g]indole-2,7-dicarboxylate and dimethyl 1,6dihydroindolo[5,4-e]indole-2,7-dicarboxylate, were succesfully prepared by the Hemetsberger indole sythesis. The ester functionality on the C-2 position was used for the further elaboration of these tetracyclic systems.

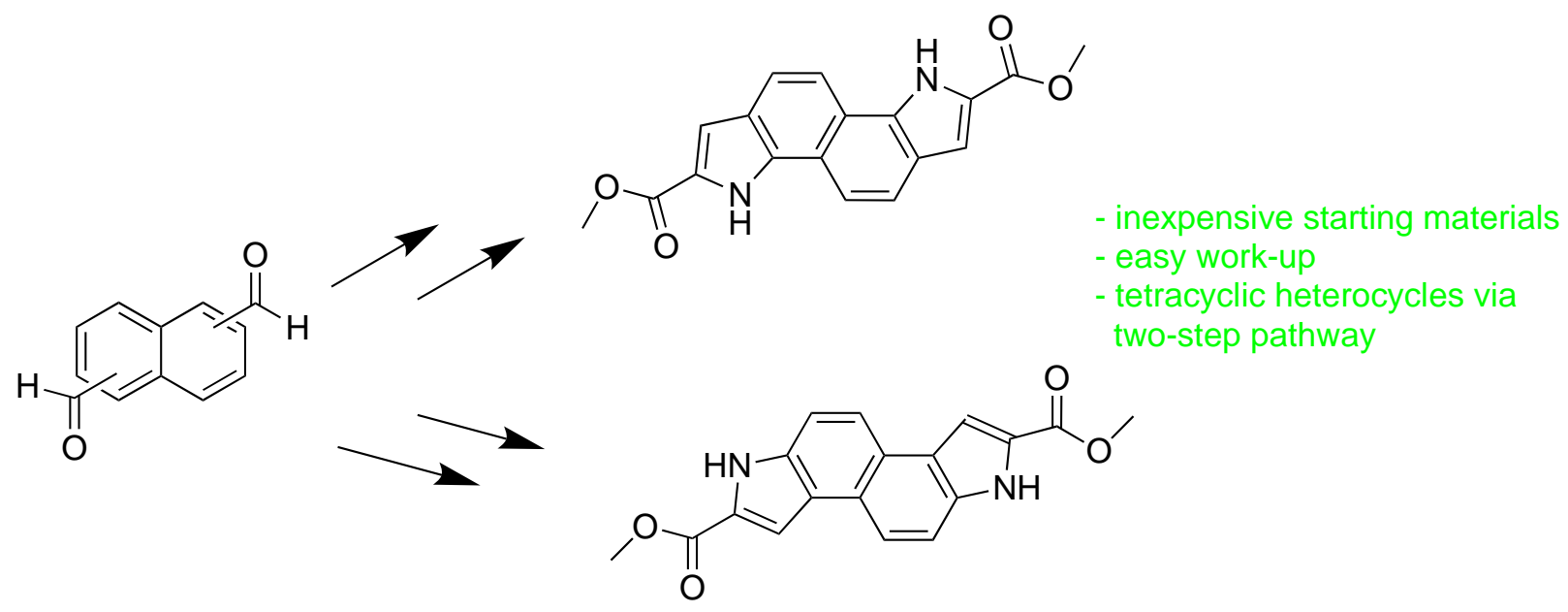

Derivatization

Keywords: Naphthalenedicarbaldehydes, Hemetsberger synthesis, dihydroindoloindoles, tetracyclic heterocycles 


\section{Introduction}

Polycyclic indole systems are biologically valuable scaffolds that occur in many natural alkaloids and considerable effort has been devoted to the synthesis of these complex and pharmacologically active molecules. ${ }^{1,2}$ Indoloindoles are an important class of polycyclic indolic compounds in which two indole structures are fused to have in common carbon atoms of the pyrrole ring, to give 5,10-dihydroindolo[3,2b]indole 1, or the benzene ring to give 1,6-dihydroindolo[7,6-g]indole, 3 and 3,8-dihydroindolo[4,5-e]indole10-one 4; fusion of an indole with an isoindole through the carbon and nitrogen atoms of the pyrrole rings give $6 \mathrm{H}$-isoindolo[2,1-a]indol-6-one 2 (Figure 1). The design and synthesis of indoloindole compounds have attracted the attention of researchers since they have allowed the investigation of several new indole systems as biologically and photophysically important targets. 3,4<smiles>c1ccc2c(c1)Nc1ccccc1N2</smiles>

1<smiles>O=C1c2ccccc2-c2cc3ccccc3n21</smiles>

2<smiles>c1cc2ccc3c(ccc4cc[nH]c43)c2[nH]1</smiles>

3<smiles></smiles>

4

Figure 1. Examples of dihydroindoloindole structures.

Boussard et al. reported that the indenoindolone 5 demonstrates high affinity for the melatonin MT 3 binding site. ${ }^{5}$ Moreover, there has also been a significant interest in the indolo[3,2-b]indole scaffold due to its photophysical properties. ${ }^{6}$ Poly-(5,10-dihexyl-5,10-dihydroindolo[3,2-b]indole-2,7-diyl) (6), 5,10-dimethyl-5, 10-dihydroindolo[3,2-b]indole 7 and 2,7-(diethoxycarbonyl)-5,10-dihydroindolo[3,2-b]indole 8 have been synthesised as high-spin polymeric materials for light emitting diodes ${ }^{7-10}$ (Figure 2).<smiles>O=C1c2ccccc2-c2[nH]c3ccc(O)cc3c21</smiles>

5<smiles>Cn1c2ccccc2c2c1c1ccccc1n2C</smiles>

7

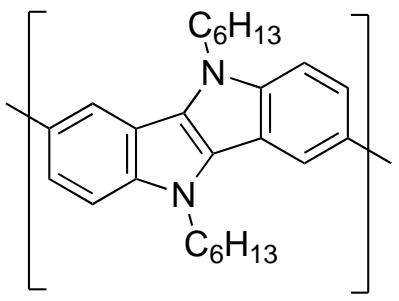

6<smiles>CCOC(=O)c1ccc2c(c1)[nH]c1cc(C(=O)OCC)ccc12</smiles>

8

Figure 2. Biologically and photophysically important dihydroindoloindole systems. 
In 1884 Golubeva was the first to synthesise the indoloindole systems by the reduction of $0,0^{\prime}$-dinitrobenzil with metal catalysts under acidic conditions, ${ }^{11}$ however the structure clarification was achieved later, by Kliegl and Haas, who described it as a doubly fused indole. ${ }^{12}$ Since that time, a variety of synthetic strategies have been employed to construct the indoloindole fragments 1, 2, 3 and $\mathbf{4}$ (Figure 1). However, there has been a particular interest in the synthesis of indoloindole systems $\mathbf{3}$ and $\mathbf{4}$ due to the fact that their reactive pyrrole ring would enable the construction of diverse synthetic analogues of indoles. The first indoloindole analogue, $1 \mathrm{H}, 6 \mathrm{H}$-indolo[7,6-g]indole-2,3,7,8-tetraone $9,^{13}$ was prepared starting with 1,5-naphthalenediamine and diethyl oxalate under acidic conditions and subsequent hydrolysis of the intermediate diester with potassium hydroxide and neutralisation with $\mathrm{HCl}$. 1,5-Dihydroxynaphthalene was also used as a starting material for the preparation of the indolo[7,6-g]indole scaffold $3 .^{14}$ In addition, isopropyl methyl napththalenedihydrazones undergo Fischer cyclisation to give a range of methyl substituted indoloindole derivatives 10-12 (Figure 3). ${ }^{15}$ The Fischer cyclisation of 1,5-, 2,6-, and 2,7- ethyl pyruvate napththalenedihydrazones under acidic conditions gave dicarboxylic acids of indolo[7,6-g]indole and thermal decarboxylation gave the unsubstituted indoloindoles. $^{16-18}$

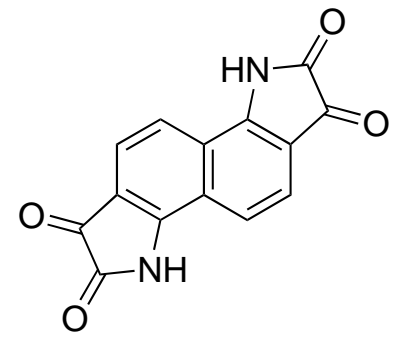

9

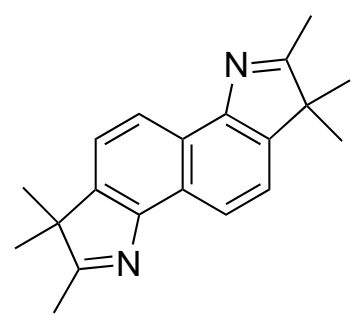

10

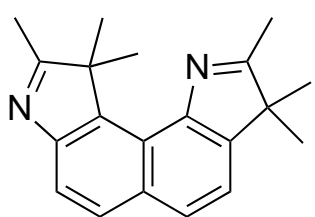

11

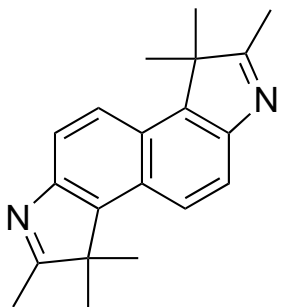

12

Figure 3. Indoloindole systems derived from different synthetic strategies.

As part of an ongoing investigation into the chemistry of indoloindole systems, it was decided to apply the Hemetsberger strategy to the preparation of indolo[7,6-g]indole derivatives. The Hemetsberger reaction ${ }^{19,20}$ is potentially one of the most important methods for the synthesis of indoles by means of a strategy based on the ready formation of indole-2-carboxylic acid derivatives which are useful precursors for functional variation. $^{21,22}$ The reaction proceeds via vinyl azides generated by the condensation of the corresponding carbaldehydes with ethyl azidoacetate. The thermal decomposition of vinyl azides followed by intramolecular cyclisation gives the targeted indoles. Herein, we report the application of the Hemetsberger indole synthesis for the first time to the construction of indoloindole systems, by the use of naphthalene dialdehydes as readily available starting materials derived from the corresponding inexpensive naphthalene derivatives.

\section{Results and Discussion}

Initially, the behaviour of the simple naphthalene-2,6-dicarbaldehyde $\mathbf{1 3}$ was investigated and the dialdehyde was prepared according to the literature. ${ }^{23}$ Reaction of naphthalene-2,6-dicarbaldehyde 13 with twenty equivalents of methyl azidoacetate in the presence of sodium methoxide, as a strong base, afforded the azido intermediate 14 which could not be obtained analytically pure but which directly underwent cyclisation in xylene to give the new indolo[7,6-g]indole 15 (Scheme 1). 


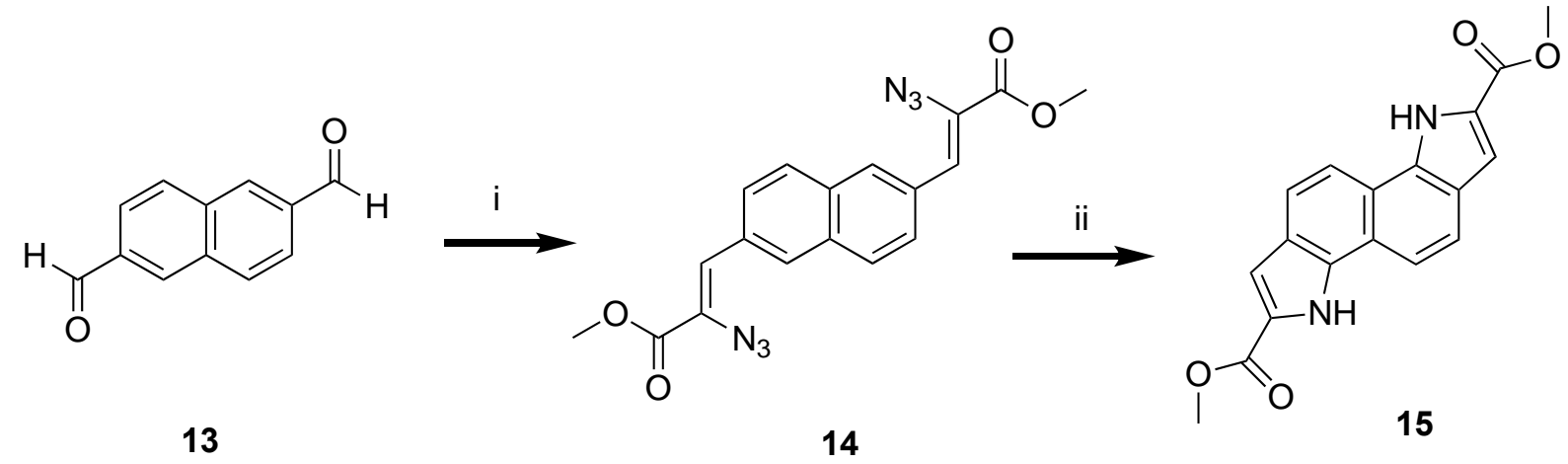

Scheme 1. Reagents and conditions: i: $\mathrm{N}_{3} \mathrm{CH}_{2} \mathrm{CO}_{2} \mathrm{Me}, \mathrm{NaOMe}$, anhyd. $\mathrm{MeOH}<-10{ }^{\circ} \mathrm{C}, 4 \mathrm{~h}, 78 \%$, ii: xylene reflux, $6 \mathrm{~h}$.

The symmetrical structure of the indoloindole 15 was confirmed by its ${ }^{1} \mathrm{H}$ NMR spectrum, which showed only a pair of doublets for $\mathrm{H} 4, \mathrm{H} 5, \mathrm{H} 9$ and $\mathrm{H} 10$. Due to the symmetrical nature of the structure, $\mathrm{H} 4$ and $\mathrm{H} 9$ resonated as a doublet at $\delta 7.86 \mathrm{ppm}$ while $\mathrm{H} 5$ and $\mathrm{H} 10$ resonated at $\delta 8.53 \mathrm{ppm}$.

Having successfully synthesised the target indole, an exploratory investigation into the reactivity of this compound was also carried out. In connection with some interesting pharmacological studies being conducted on a variety of 2-substituted indole systems it was decided to elaborate the 2-position on the newly synthesised indoloindole (Scheme 2). 2-Hydroxymethylindole scaffolds have been used as key compounds to build various classes of complex bioactive molecules and examples of such compounds have been utilised in the synthesis of pharmacologically active indole alkaloids. ${ }^{24-26}$

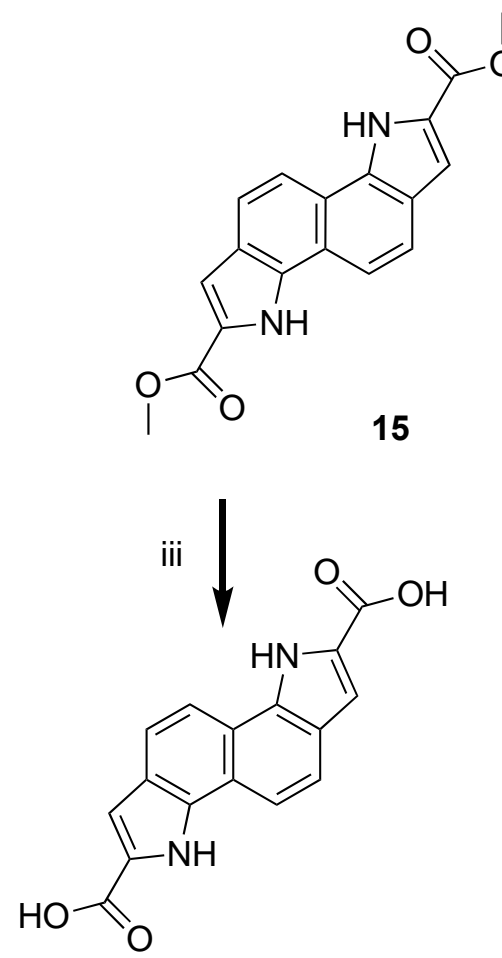

18
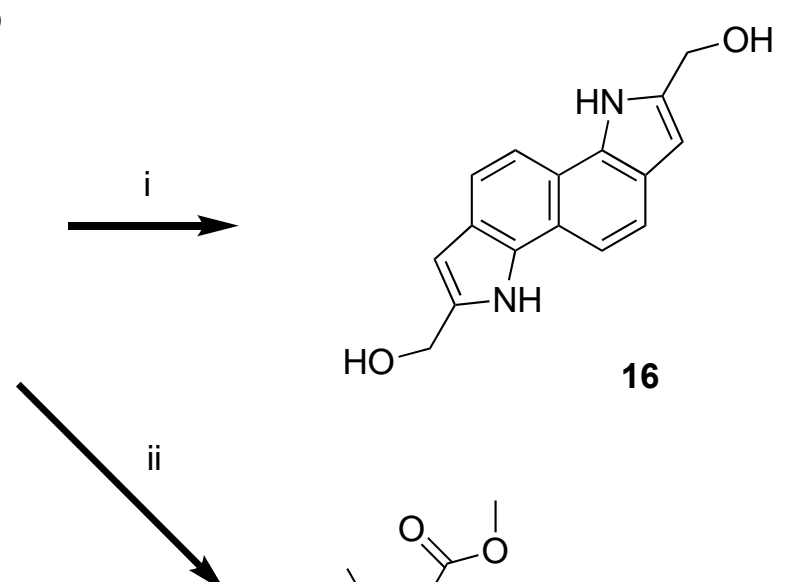

16<smiles>C=C(O)c1cc2ccc3c(ccc4cc(C(=O)OC)n(C)c43)c2n1C</smiles>

17

Scheme 2. Reagents and conditions: i: THF, $\mathrm{LiAlH}_{4}$, ice-salt slurry, rt, $4,5 \mathrm{~h}$ ii: $\mathrm{KOH}, \mathrm{Mel}, \mathrm{DMSO}, \mathrm{rt}, 3,5 \mathrm{~h}$ iii: $\mathrm{KOH} / \mathrm{HCl}, \mathrm{EtOH} / \mathrm{H}_{2} \mathrm{O}$, reflux, 35 min iv: $\mathrm{POCl}_{3}, \mathrm{DMF}$, rt, overnight. 
The treatment of indoloindole compound $\mathbf{1 5}$ with lithium aluminium hydride in THF at room temperature afforded the corresponding 2-hydoxymethylindoloindole 16 in excellent yield (Scheme 2). The most important feature in the ${ }^{1} \mathrm{H}$ NMR spectrum of this compound was the absence of the methyl ester protons and the appearance of the methylene protons of the hydroxymethyl groups as a doublet at $4.64 \mathrm{ppm}$ with a coupling constant of $5.3 \mathrm{~Hz}$ and the hydroxyl protons at $2.07 \mathrm{ppm}$ as a broad singlet.

It was also decided to investigate the preparation of indoloindole-2-carboxylic acid systems which would provide key precursors for further exploratory investigations. The indoloindole $\mathbf{1 5}$ was hydrolysed by heating under reflux in aqueous ethanolic $\mathrm{KOH}$ solution to give the dicarboxylic acid $\mathbf{1 8}$ as a dark yellow powder in $\mathbf{8 5 \%}$ yield (Scheme 2). As expected, the ${ }^{1} \mathrm{H}$ NMR spectrum of the diacid $\mathbf{1 8}$ showed the absence of the methyl-ester group.

The indoloindole diester $\mathbf{1 5}$ was found to be rather insoluble in most solvent systems. Therefore, the more soluble $\mathrm{N}$-methyl derivative $\mathbf{1 7}$ of this compound was prepared and could easily be used for further investigations (Scheme 2). The $\mathrm{N}$-methylation was carried out with methyl iodide in DMSO containing $\mathrm{KOH}$. $\mathrm{A}$ consequence of $\mathrm{N}$-methylation for the ${ }^{1} \mathrm{H}$ NMR spectrum of compound 17 was the loss of the $\mathrm{NH}$ proton and the appearance of the methyl protons as singlets at $4.81 \mathrm{ppm}$.

The $N, N^{\prime}$-dimethylindoloindole compound 17 , which is much more soluble in DMF than the indoloindole ester 15, was formylated using phosphoryl chloride in DMF to give the diformyl indoloindole ester 19 in moderate yield (Scheme 2). Vilsmeier formylation ${ }^{27}$ is not only an excellent indicator for the identification of reactivity and regioselectivity but also delivers in this case a dialdehyde, which can be used for further useful synthetic transformations. The ${ }^{1} \mathrm{H}$ NMR spectrum of the product showed the aldehyde signal at $10.06 \mathrm{ppm}$.

Given the success of naphthalene-2,6-dialdehyde towards the Hemetsberger reaction, the reactivity of naphthalene-1,5-dialdehyde $\mathbf{2 0}$ for the preparation of indoloindole systems was also investigated. It was anticipated that the expected indoloindole structure $\mathbf{2 2}$ would be structurally isomeric with indoloindole 15. The designated dicarbaldehyde $\mathbf{2 0}$ was prepared according to the literature. ${ }^{28,29}$ The Hemetsberger reaction conditions were applied to naphthalene-1,5-dicarbaldehyde $\mathbf{2 0}$ and the intermediate vinyl azide $\mathbf{2 1}$ was isolated in moderate yield. This could not be obtained analytically pure but was directly submitted to thermal decomposition to give the expected dimethyl indolo[5,4-e]indole-ester 22 in good yield (Scheme 3). The indolo[5,4-e]indole 22 has previously been synthesised by Samsoniya and co-workers by the cyclisation of dihydrazones of the 2,7- and 2,6-ethyl pyruvate substituted naphthalenes. ${ }^{30}$ However, the Hemetsberger indole synthesis applied in this current work offers a very attractive alternative.

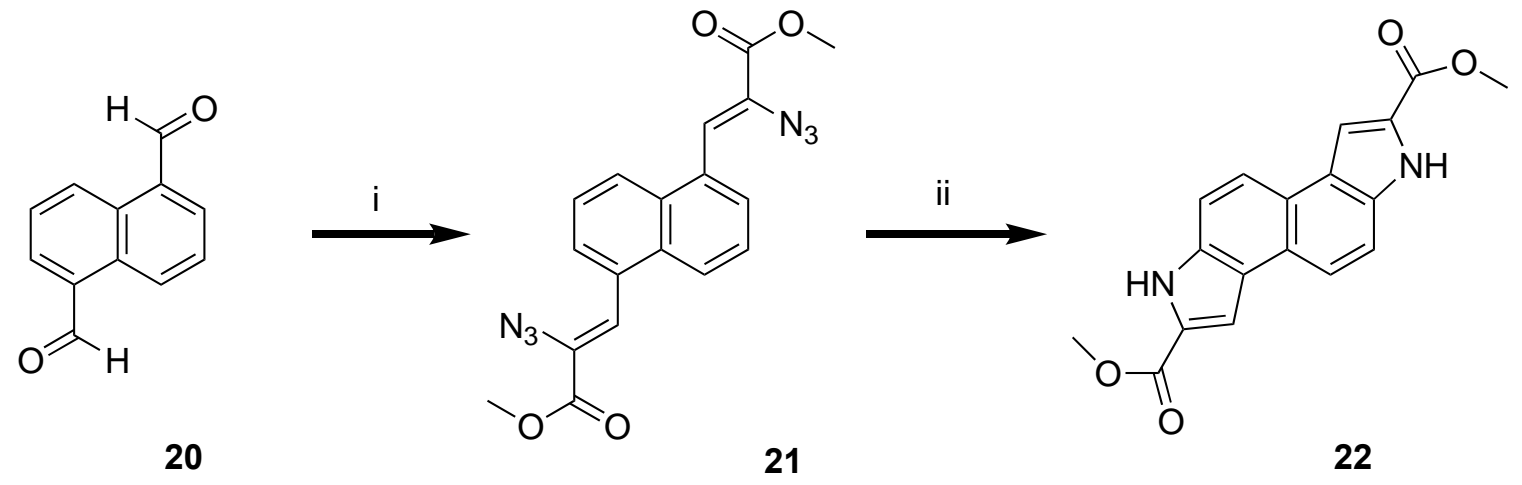

Scheme 3. Reagents and conditions: i: $\mathrm{N}_{3} \mathrm{CH}_{2} \mathrm{CO}_{2} \mathrm{Me}, \mathrm{NaOMe}$, anhyd. $\mathrm{MeOH}<-10{ }^{\circ} \mathrm{C}, 4 \mathrm{~h}, 67 \%$, ii: xylene reflux, $6 \mathrm{~h}$. 
The ${ }^{1} \mathrm{H}$ NMR spectrum of compound 22 showed ortho spin-spin coupling between $\mathrm{H} 4$ and $\mathrm{H} 5$, and $\mathrm{H} 9$ and $\mathrm{H} 10$ confirming the symmetrical angular structure. The chemical shifts of $\mathrm{H} 4$ and $\mathrm{H} 9$ were shifted downfield as a doublet at $8.24 \mathrm{ppm}$ and the $\mathrm{H} 3$ and $\mathrm{H} 8$ protons were moved upfield to $7.79 \mathrm{ppm}$, compared to the previous indoloindole 15.

In a further investigation, the ester $\mathbf{2 2}$ was reduced with lithium aluminium hydride in tetrahydrofuran to give the hydroxymethylindoloindole 23 as a green solid in excellent yield (Scheme 4). The ${ }^{1} \mathrm{H}$ NMR spectrum of compound 23 showed the presence of methylene protons at $4.69 \mathrm{ppm}$ as a doublet with a coupling constant of $5.5 \mathrm{~Hz}$ and the hydroxyl protons as a broad singlet at $2.11 \mathrm{ppm}$. The methyl ester protons present in the starting material 22 were absent.
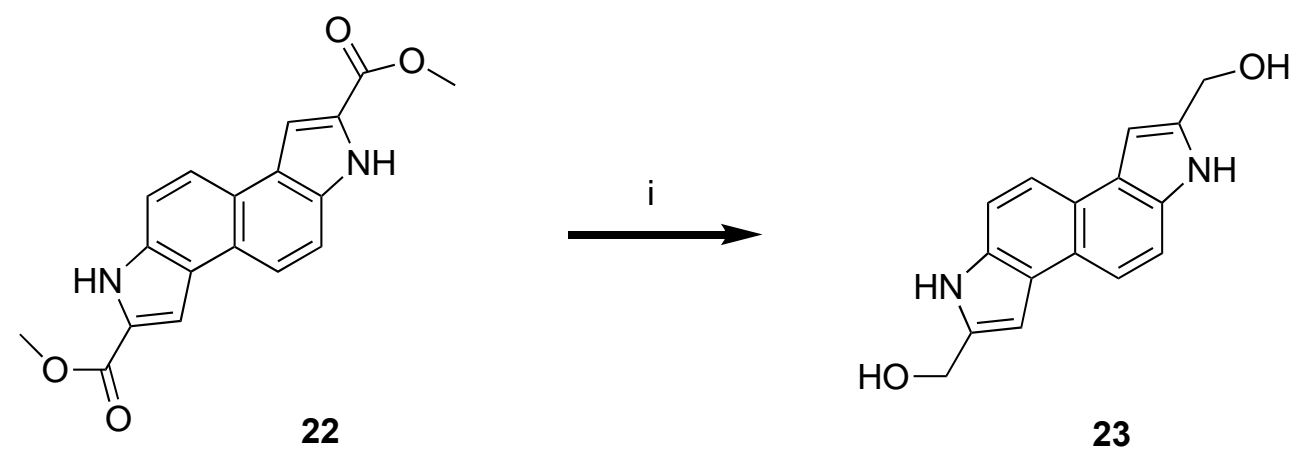

Scheme 4. Reagents and conditions: i: THF, $\mathrm{LiAlH}_{4}$, ice-salt slurry, rt, 4,5 h.

\section{Conclusions}

A versatile methodology is introduced for the synthesis of indolo[7,6-g]indole by the use of the reactivity of naphthalene-2,6-dicarbaldehyde and naphthalene-1,5-dicarbaldehyde. The Hemetsberger indole synthesis offers a simple methodology for the compounds belonging to the class of indoloindole systems. The overall process uses simple reaction conditions with inexpensive reagents and relatively few steps, and with attendant good yields therefore provides a convenient and valuable method for the synthesis of indoloindole systems. Some initial elaboration of these indoloindole systems has been carried out, but more wide-ranging studies remain to be fully investigated.

\section{Experimental Section}

All reagents and solvents were obtained from commercial sources and appropriately purified, if necessary. Melting points were measured using a Mel-Temp melting point apparatus, and are uncorrected. Microanalyses were performed on a Carlo Erba Elemental Analyzer EA 1108 at the Campbell Microanalytical Laboratory, University of Otago, New Zealand. Infrared spectra were recorded with a Thermo Nicolet 370 FTIR spectrometer using potassium bromide disks. Ultraviolet-visible spectra were recorded in analytical grade methanol using a Varian Cary 100 Scan spectrometer and the absorption maxima together with the molar absorptivity $(\varepsilon)$ are reported. NMR spectra were recorded in the designated solvents on a Bruker Avance DPX300 (300 MHz) at the designated frequency and were internally referenced to the solvent peaks. High- 
resolution mass spectra were performed at the Campbell Microanalytical Laboratory, University of Otago, New Zealand. Pressure column chromatography was carried out using Merck 230-400 mesh ASTM silica gel. Vacuum column chromatography was carried out using Merck $60 \mathrm{H}$ silica gel. Gravity column chromatography was carried out using Merck 70-230 mesh ASTM silica gel. Preparative thin layer chromatography was carried out on $3 \times 200 \times 200 \mathrm{~mm}$ glass plates coated with Merck $60 \mathrm{GF}_{254}$ silica gel. Reactions were monitored using thin layer chromatography, performed on Merck DC aluminium foil coated with silica gel $\mathrm{GF}_{254}$.

\section{General procedure 1, for the preparation of vinyl-azido intermediates}

A solution of sodium methoxide was prepared via the portion-wise addition of metallic sodium (1.77 g, 76.95 $\mathrm{mmol})$ to anhydrous methanol $(30 \mathrm{~mL})$ with stirring under nitrogen. The methoxide solution was stirred and cooled in an ice-salt slurry during the dropwise addition of a solution containing the dimethoxybenzaldehyde derivative $(0.77 \mathrm{~g}, 4.65 \mathrm{mmol})$ and either methyl azidoacetate $(5.37 \mathrm{~g}, 46.5 \mathrm{mmol})$ or ethyl azidoacetate (5.85 $\mathrm{g}, 46.5 \mathrm{mmol})$ in anhydrous methanol $(15 \mathrm{~mL})$ over $1.5 \mathrm{~h}$, under nitrogen atmosphere. The mixture was stirred further for $5 \mathrm{~h}$ with cooling and then poured onto crushed ice. The resulting precipitate was filtered, washed with water and dried to give the title compound.

\section{General procedure 2, for the preparation of indoloindole methyl esters}

A solution of vinyl-azido intermediate $(2.24 \mathrm{~g}, 8.53 \mathrm{mmol})$ in either xylene $(35 \mathrm{~mL})$ was added dropwise over $45 \mathrm{~min}$ to a stirred solution of xylene $(10 \mathrm{~mL})$ or 1,2 -dichlorobenzene $(10 \mathrm{~mL})$ and the resulting mixture was heated at reflux for $6 \mathrm{~h}$. The solvent was then distilled under reduced pressure and the residue was recrystallized from dichloromethane and $n$-hexane to give the title compound.

\section{General procedure 3, for the reduction of methyl ester groups}

A suspension of lithium aluminium hydride $(3.18 \mathrm{~g}, 83.8 \mathrm{mmol})$ in anhydrous tetrahydrofuran $(50 \mathrm{~mL}) \mathrm{was}$ cooled in an ice-salt bath and a solution of indole-2-carboxylate derivative $(2.00 \mathrm{~g}, 8.50 \mathrm{mmol})$ in anhydrous tetrahydrofuran $(100 \mathrm{~mL})$ was added dropwise over a period of $1 \mathrm{~h}$ under nitrogen atmosphere. The mixture was stirred with cooling for $2 \mathrm{~h}$, and at ambient temperature overnight. The mixture was again cooled and cautiously treated sequentially with $5 \mathrm{M} \mathrm{NaOH}(10.5 \mathrm{~mL})$ and then water $(10.5 \mathrm{~mL})$. The resulting granular solid was filtered and washed with ethyl acetate. The combined filtrate was washed twice with brine, dried with anhydrous sodium sulfate, and the solvent evaporated under reduced pressure to give the title compound.

2,6-Diformylnaphthalene ${ }^{\mathbf{2 3}}$ (13). The title compound was prepared according to the literature as a yellow solid; m.p. $192{ }^{\circ} \mathrm{C}$ (lit. ${ }^{23}$ m.p. $190-192{ }^{\circ} \mathrm{C}$ ); ${ }^{1} \mathrm{H}$ NMR (300 MHz, $d_{6}$-DMSO): $\delta 10.15$ (2 H, s, CHO), $8.34(2 \mathrm{H}, \mathrm{d}, J$ $6.9 \mathrm{~Hz}, \mathrm{H} 1$ and H5), $8.02(2 \mathrm{H}, \mathrm{d}, J 7.2 \mathrm{~Hz}, \mathrm{H} 3, \mathrm{H} 7), 8.01(2 \mathrm{H}, \mathrm{d}, J 8.6 \mathrm{~Hz}, \mathrm{H} 4, \mathrm{H} 8) ;{ }^{13} \mathrm{C} \mathrm{NMR}\left(\mathrm{CDCl}_{3}\right): \delta 192.24$ (ㄷHO), 136.61 (C2, C6), 136.17 (aryl C), 134.15 (C1, C5), 131.05 (C4, C8) and 124.54 (C3, C7).

(2Z,2'Z)-Dimethyl 3,3'-(naphthalene-2,6-diyl)bis(2-azidoacrylate) (14). The title compound was prepared as described for the general procedure 1 from 2,6-diformylnaphthalene (13) (3.10 g, 16.8 mmol) and ethyl azidoacetate $(21.3 \mathrm{~g}, 186 \mathrm{mmol})$ in anhydrous methanol $(30 \mathrm{~mL})$. After partial purification, the title compound (4.33 g, 68\%) was obtained as a pale yellow granular solid; m.p. $256{ }^{\circ} \mathrm{C} ; v_{\text {max }}: 2125 \mathrm{~s}, 1713 \mathrm{~s}, 1435 \mathrm{~s}, 1386 \mathrm{~s}$, 1344 s, 1285 m, 1256 m, 1086 s, $909 \mathrm{w} \mathrm{cm}^{-1}$; $\lambda_{\text {max }}: 358 \mathrm{~nm}\left(\varepsilon\right.$ 189,076 cm $\left.{ }^{-1} \mathrm{M}^{-1}\right), 282(183,625), 204$ (179,461); ${ }^{1} \mathrm{H}$ NMR (300 MHz, $d_{6}$-DMSO): $\delta 8.19(2 \mathrm{H}, \mathrm{s}, \mathrm{CH}=\mathrm{C}), 7.87\left(2 \mathrm{H}, \mathrm{d}, J 4.6 \mathrm{~Hz}, \mathrm{H1}{ }^{\prime}, \mathrm{H} 5^{\prime}\right), 7.77\left(2 \mathrm{H}, \mathrm{d}, J 8.6 \mathrm{~Hz}, \mathrm{H} 4^{\prime}\right.$, $\left.\mathrm{H} 8^{\prime}\right), 6.98\left(2 \mathrm{H}, \mathrm{d}, J 7.6 \mathrm{~Hz}, \mathrm{H}^{\prime}, \mathrm{H} 7^{\prime}\right), 3.88\left(6 \mathrm{H}, \mathrm{s}, \mathrm{CO}_{2} \mathrm{Me}\right) ;{ }^{13} \mathrm{C} N M R\left(d_{6}-\mathrm{DMSO}\right): \delta 164.38\left(\underline{\mathrm{CO}}{ }_{2} \mathrm{Me}\right), 133.59$ $(\mathrm{CH}=\mathrm{C}), 132.37\left(\mathrm{C2}^{\prime}, \mathrm{C}^{\prime}\right)$, and 130.88 (aryl C), $129.17\left(\mathrm{C1}^{\prime}, \mathrm{C} 5^{\prime}\right), 128.42\left(\mathrm{C4}^{\prime}, \mathrm{C} 8^{\prime}\right), 126.38\left(\mathrm{C3}^{\prime}, \mathrm{C} 7^{\prime}\right), 125.54$ $(\underline{\mathrm{CH}}=\mathrm{C}), 53.43\left(\mathrm{CO}_{2} \underline{\mathrm{Me}}\right)$. Satisfactory analytical or HRMS data could not be obtained.

Dimethyl 3,8-dihydroindolo[7,6-g]indole-2,7-dicarboxylate (15). The title compound was prepared as described for the general procedure 2 from (2Z,2'Z)-dimethyl 3,3'-(naphthalene-2,6-diyl)bis(2-azidoacrylate) (14) $(2.50 \mathrm{~g}, 6.6 \mathrm{mmol})$ in xylene $(40 \mathrm{ml})$. After purification, the title compound $(1.38 \mathrm{~g}, 65 \%)$ was obtained as a 
yellow granular solid; m.p. 298 ㅇ; $v_{\text {max: }} 3325$ brs, 3276 brm, 1686 s, 1550 s, 1501 s, 1441 s, 1284 m, 1220 m, $1237 \mathrm{~m}, 1002 \mathrm{~s}, 832 \mathrm{~s}, 719 \mathrm{~s}, 760 \mathrm{~s} \mathrm{~cm}^{-1} ; \lambda_{\max }: 365 \mathrm{~nm}\left(\varepsilon 30,498 \mathrm{~cm}^{-1} \mathrm{M}^{-1}\right), 343(25,890), 271(15,690), 204$ (29,890); ${ }^{1} \mathrm{H}$ NMR (300 MHz, $d_{6}$-DMSO): $\delta 12.72(2 \mathrm{H}, \mathrm{s}, \mathrm{NH}), 8.53(2 \mathrm{H}, \mathrm{d}, J 6.7 \mathrm{~Hz}, \mathrm{H} 4, \mathrm{H} 9), 7.86(2 \mathrm{H}, \mathrm{d}, J 8.7$

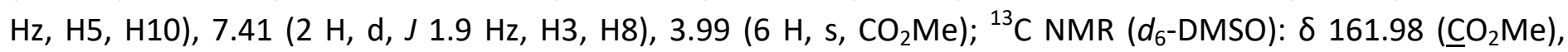
134.71 (aryl C), 126.41 (aryl C), 123.76 ( $\mathrm{CH}=\underline{\mathrm{C}}), 121.06$ (C5, C10), 119.67 (C4, C9), 116.29 (aryl C), 101.10 $(\underline{\mathrm{CH}}=\mathrm{C}), 52.09\left(\mathrm{CO}_{2} \underline{\mathrm{Me}}\right) ; \mathrm{HRMS}\left({ }^{+} \mathrm{ESI}\right): \mathrm{C}_{18} \mathrm{H}_{13} \mathrm{~N}_{2} \mathrm{O}_{4}[\mathrm{M}-\mathrm{H}]^{+}$requires 321.0875 , found 321.0887.

3,8-Dihydroindolo[7,6-g]indole-2,7-dimethanol (16). The title compound was prepared as described for the general procedure 3 from dimethyl 3,8-dihydroindolo[7,6-g]indole-2,7-dicarboxylate (15) (1.00 g, $3.1 \mathrm{mmol})$ and lithium aluminium hydride $(3.2 \mathrm{~g}, 168 \mathrm{mmol})$ in anhydrous tetrahydrofuran $60 \mathrm{~mL})$. After filtration and crystallization from chloroform, the title compound $(0.504 \mathrm{~g}, 61 \%)$ was obtained as a pale green granular solid; m.p. 334 o. ; (Found: $\mathrm{C}, 53.1 ; \mathrm{H}, 3.6 ; \mathrm{N}, 7.2 . \mathrm{C}_{16} \mathrm{H}_{14} \mathrm{~N}_{2} \mathrm{O}_{2} .0 .1 \mathrm{CHCl}_{3}$ requires $\mathrm{C}, 52.9 ; \mathrm{H}, 3.9 ; \mathrm{N}, 7.3 \%$ ); $v_{\text {max }}: 3507$ brs, 3267 brs, 1372 s, 1280 s, 1134 m, 1014 s, 1007 s, 976 s, 824 s, 721 s, 702 m, 511 w cm $^{-1} ; \lambda_{\max }: 355$ nm (ع 6,231 cm $\left.{ }^{-1} \mathrm{M}^{-1}\right)$, 339 (72,44), 298 (16,115), 268 (58,368), 204 (29,311); ${ }^{1} \mathrm{H}$ NMR (300 MHz, $d_{6}$-DMSO): $\delta 11.64(2$ $\mathrm{H}, \mathrm{s}, \mathrm{NH}), 7.94(2 \mathrm{H}, \mathrm{d}, \mathrm{J} 8.4 \mathrm{~Hz}, \mathrm{H} 4, \mathrm{H} 9), 7.57(2 \mathrm{H}, \mathrm{d}, \mathrm{J} 8.5 \mathrm{~Hz}, \mathrm{H} 5, \mathrm{H} 10), 7.39(2 \mathrm{H}, \mathrm{d}, \mathrm{J} 1.9 \mathrm{~Hz}, \mathrm{H} 3, \mathrm{H} 8), 4.64(4 \mathrm{H}$,

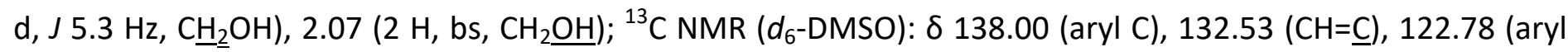

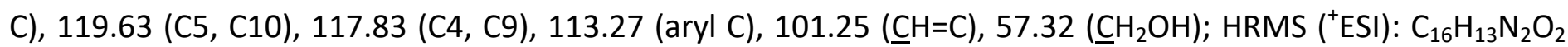
$[\mathrm{M}-\mathrm{H}]^{+}$requires 265.0977, found 265.0993.

Dimethyl 3,8-dimethyl-3,8-dihydroindolo[7,6-g]indole-2,7-dicarboxylate (17). A solution of dimethyl 3,8dihydroindolo[7,6-g]indole-2,7-dicarboxylate (15) $(2.00 \mathrm{~g}, .6 .2 \mathrm{mmol})$ in DMSO $(20 \mathrm{~mL})$ was stirred with $\mathrm{KOH}$ $(1.26 \mathrm{~g}, 22 \mathrm{mmol})$ for $1 \mathrm{~h}$ at room temperature. Methyl iodide $(0.9 \mathrm{~mL}, 14.4 \mathrm{mmol})$ was added and stirring continued for $2.5 \mathrm{~h}$ before ice water was added. The resulting precipitate was filtered, washed with water, dried to give the title compound $(2.07 \mathrm{~g}, 95 \%)$ as a golden solid; m.p. 286 우; $v_{\max }: 3412$ brm, $1700 \mathrm{~s}, 1487 \mathrm{~s}$,

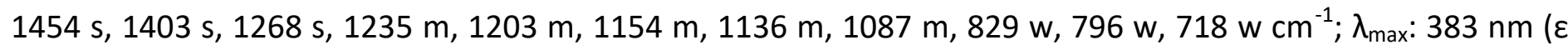
6,685 cm $\left.{ }^{-1} \mathrm{M}^{-1}\right), 343(11,713), 286(20,244), 204(17,895) ;{ }^{1} \mathrm{H}$ NMR $\left(300 \mathrm{MHz}, d_{6}\right.$-DMSO): $\delta 8.31(2 \mathrm{H}, \mathrm{d}, J 8.8 \mathrm{~Hz}$, $\mathrm{H} 5, \mathrm{H} 10), 7.66(2 \mathrm{H}, \mathrm{d}, J 8.9 \mathrm{~Hz}, \mathrm{H} 4, \mathrm{H} 9), 7.39(2 \mathrm{H}, \mathrm{d}, \mathrm{J} 1.9 \mathrm{~Hz}, \mathrm{H} 3, \mathrm{H} 8), 4.54(6 \mathrm{H}, \mathrm{s}, \mathrm{NMe}) 3.87\left(6 \mathrm{H}, \mathrm{s}, \mathrm{CO}_{2} \mathrm{Me}\right)$; ${ }^{13} \mathrm{C}$ NMR $\left(d_{6}\right.$-DMSO): $\delta 161.52$ ( $\left.\underline{C O}_{2} \mathrm{Me}\right), 135.58$ (aryl C), 126.97 (aryl C), $122.09(\mathrm{CH}=\underline{\mathrm{C}}), 120.70(\mathrm{C} 5, \mathrm{C} 10)$, 119.49 (C4, C9), 115.34 (aryl C), $110.80(\underline{\mathrm{CH}}=\mathrm{C}), 50.70\left(\mathrm{CO}_{2} \underline{\mathrm{Me}}\right), 35.88$ (NMe); HRMS ( $\left.{ }^{+} \mathrm{ESI}\right): \mathrm{C}_{20} \mathrm{H}_{18} \mathrm{~N}_{2} \mathrm{NaO}_{4}$ $[\mathrm{M}+\mathrm{Na}]^{+}$requires 373.1164 , found 373.1124 .

3,8-Dihydroindolo[7,6-g]indole-2,7-dicarboxylic acid (18). Dimethyl 3,8-dihydroindolo[7,6-g]indole-2,7dicarboxylate $(1.00 \mathrm{~g}, 3.1 \mathrm{mmol})$ (15) was refluxed in aqueous/ethanolic (1:1) $\mathrm{KOH}(0.5 \mathrm{M}, 40 \mathrm{~mL})$ for $35 \mathrm{~min}$. After cooling, the yellow solution was acidified with $5 \mathrm{M} \mathrm{HCl}$ and the resulting precipitate filtered through a frit. The precipitate was washed with water and dried to give the title compound $(0.82 \mathrm{~g}, 90 \%)$ as a yellow powder; m.p. $346{ }^{\circ} \mathrm{C}$; v max: 3508 brm, 3317 brm, 1663 s, 1558 s, 1507 s, 1438 s, 1337 s, 1278 m, 1197 m, 1224 m, $832 \mathrm{~s}, 717 \mathrm{~s}, 586 \mathrm{~s} \mathrm{~cm}^{-1} ; \lambda_{\max }: 368 \mathrm{~nm}\left(\varepsilon 36,120 \mathrm{~cm}^{-1} \mathrm{M}^{-1}\right), 351(31,350), 327(39,750) ;{ }^{1} \mathrm{H} \mathrm{NMR}\left(300 \mathrm{MHz}, d_{6^{-}}\right.$ DMSO): $\delta 12.54(2 \mathrm{H}, \mathrm{s}, \mathrm{NH}), 8.49(2 \mathrm{H}, \mathrm{d}, J 8.7 \mathrm{~Hz}, \mathrm{H} 4, \mathrm{H} 9), 7.80(2 \mathrm{H}, \mathrm{d}, J 9.1 \mathrm{~Hz}, \mathrm{H} 5, \mathrm{H} 10), 7.31$ (2 H, d, J 1.9 $\mathrm{Hz}, \mathrm{H3}, \mathrm{H} 8) ;{ }^{13} \mathrm{C}$ NMR $\left(d_{6}\right.$-DMSO): $\delta 163.08\left(\mathrm{CO}_{2} \mathrm{H}\right), 134.48\left(\operatorname{aryl~C~C1}{ }^{\prime}, \mathrm{C}^{\prime}\right), 127.61$ (aryl C C2', C6'), 123.70 $(\mathrm{CH}=\underline{\mathrm{C}}), 120.95\left(\mathrm{C}^{\prime}, \mathrm{C} 8^{\prime}\right), 119.54\left(\mathrm{C}^{\prime}, \mathrm{C}^{\prime}\right), 116.04(\operatorname{aryl} \mathrm{C}), 109.66(\underline{\mathrm{CH}}=\mathrm{C}) ; \mathrm{HRMS}\left({ }^{+} \mathrm{ESI}\right): \mathrm{C}_{16} \mathrm{H}_{9} \mathrm{~N}_{2} \mathrm{O}_{4}[\mathrm{M}-\mathrm{H}]^{+}$ requires 293.0562 , found 293.0560 .

Dimethyl 1,6-diformyl-3,8-dimethyl-3,8-dihydroindolo[7,6-g]indole-2,7-dicarboxylate (19). The title compound was prepared from dimethyl 3,8-dimethyl-3,8-dihydroindolo[7,6-g]indole-2,7-dicarboxylate (17) $(1.5 \mathrm{~g}, 4.3 \mathrm{mmol})$ and phosphoryl chloride $(1.3 \mathrm{~mL}, 13.5 \mathrm{mmol})$ in $N, N$-dimethylformamide $(15 \mathrm{~mL})$. After filtration and purification, the title compound $(0.89 \mathrm{~g}, 51 \%)$ was obtained as a golden powder; m.p. $280{ }^{\circ} \mathrm{C}$; $v_{\text {max }}: 3444$ brm, 2927 m, 1639 s, 1526 s, 1485 s, 1457 s, 1401 s, 1260 s, 1152 s, 1133 s, 1090 s, 1018 m, 924 s, 
$808 \mathrm{~s}, 722 \mathrm{w}, 619 \mathrm{w} \mathrm{cm}^{-1}$; $\lambda_{\max }: 269 \mathrm{~nm}\left(\varepsilon 75,806 \mathrm{~cm}^{-1} \mathrm{M}^{-1}\right), 204(28,193) ;{ }^{1} \mathrm{H}$ NMR (300 MHz, $d_{6}$-DMSO): $\delta 10.06$ (2 H, s, CHO), $8.71(2 \mathrm{H}, \mathrm{d}, J 9.0 \mathrm{~Hz}, \mathrm{H} 5, \mathrm{H} 10), 8.50(2 \mathrm{H}, \mathrm{d}, J 8.9 \mathrm{~Hz}, \mathrm{H} 4, \mathrm{H} 9), 4.34(6 \mathrm{H}, \mathrm{s}, \mathrm{NMe}) 3.24(6 \mathrm{H}, \mathrm{s}$, $\mathrm{CO}_{2} \mathrm{Me}$ ); ${ }^{13} \mathrm{C}$ NMR $\left(d_{6}\right.$-DMSO): $\delta 184.89$ (CO), 172.68 ( $\left.\mathrm{CO}_{2} \mathrm{Me}\right), 161.61$ (aryl C), 143.88 (aryl C), 132.20 (aryl C), 121.32 (C5, C10), 120.23 (C4, C9), 118.11 (aryl C), $113.78(\underline{\mathrm{CH}}=\mathrm{C}), 60.13\left(\mathrm{CO}_{2} \mathrm{Me}\right), 34.88$ (NMe). Satisfactory analytical or HRMS data could not be obtained.

Naphthalene-1,5-dicarbaldehyde ${ }^{\mathbf{2 8 , 2 9}}(\mathbf{2 0 )}$. The title compound was prepared according to the literature as an orange solid; m.p. $198{ }^{\circ} \mathrm{C}$ (lit. ${ }^{29}$ m.p. $198-200{ }^{\circ} \mathrm{C}$ ); ${ }^{1} \mathrm{H}$ NMR: $\left(300 \mathrm{MHz}, \mathrm{CDCl}_{3}\right) 10.32(2 \mathrm{H}, \mathrm{s}, \mathrm{CHO}), 9.55$ (2 H, dd, J $3.8 \mathrm{~Hz}, \mathrm{H} 4, \mathrm{H} 8), 8.27(2 \mathrm{H}, \mathrm{d}, J 7.2 \mathrm{~Hz}, \mathrm{H} 2, \mathrm{H} 7), 7.81(2 \mathrm{H}, \mathrm{dd}, J 3.8 \mathrm{~Hz}, \mathrm{H} 3, \mathrm{H} 6) ;{ }^{13} \mathrm{C} \mathrm{NMR}\left(\mathrm{CDCl}_{3}\right): \delta 194.03(\underline{\mathrm{C}} \mathrm{HO})$, $137.81(\mathrm{C} 2, \mathrm{C} 6), 132.35$ (C1, C5), 131.72 (C4, C8), 131.24 (aryl C) and 128.50 (C3, C7).

(2Z,2'Z)-Dimethyl 3,3'-(naphthalene-1,5-diyl)bis(2-azidoacrylate) (21). The title compound was prepared as described for the general procedure 1 from naphthalene-1,5-dicarbaldehyde (20) (2.0 g, $10.84 \mathrm{mmol})$ and ethyl azidoacetate $(13.74 \mathrm{~g}, 120 \mathrm{mmol})$ in anhydrous methanol $(20 \mathrm{~mL})$. After filtration, the title compound (3.76 g, 59\%) was obtained as a pale yellow granular solid; m.p. $242{ }^{\circ} \mathrm{C} ; v_{\text {max }}: 3393 \mathrm{~m}, 2959 \mathrm{~s} .2127 \mathrm{~s}, 1711 \mathrm{~s}$, $1611 \mathrm{~s}, 1432 \mathrm{~s}, 1153 \mathrm{~s}, 1257 \mathrm{~s}, 1280 \mathrm{~m}, 1085 \mathrm{~s}, 777 \mathrm{~s}, 660 \mathrm{w} \mathrm{cm}^{-1} ; \lambda_{\max }: 348 \mathrm{~nm}\left(\varepsilon 56,765 \mathrm{~cm}^{-1} \mathrm{M}^{-1}\right), 207$ (96,977); ${ }^{1} \mathrm{H}$ NMR (300 MHz, $d_{6}$-DMSO): $\delta 8.12(2 \mathrm{H}, \mathrm{s}, \mathrm{C} \underline{\mathrm{H}}=\mathrm{C}), 7.92\left(2 \mathrm{H}, \mathrm{d}, J 7.6 \mathrm{~Hz}, \mathrm{H} 2^{\prime}, \mathrm{H} 6^{\prime}\right), 7.63(2 \mathrm{H}, \mathrm{d}, J 7.6$

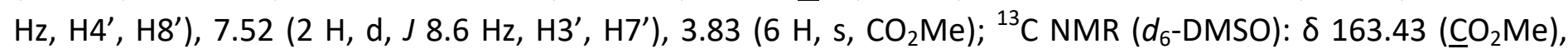
128.81 (C1', C5'), 127.45 ( $\mathrm{CH}=\mathrm{C}$ ), 126.09 (aryl C), 125.50 (C3', C7'), 122.65 (C4', C8'), 114.40 (C2', C6'), 107.81 $(\underline{\mathrm{CH}}=\mathrm{C}), 53.70\left(\mathrm{CO}_{2} \underline{\mathrm{Me}}\right)$. Satisfactory analytical or HRMS data could not be obtained.

Dimethyl 1,6-dihydroindolo[5,4-e]indole-2,7-dicarboxylate (22). The title compound was prepared as described for the general procedure 2 from (2Z,2'Z)-dimethyl 3,3'-(naphthalene-1,5-diyl)bis(2-azidoacrylate) (21) $(2.50 \mathrm{~g}, 6.6 \mathrm{mmol})$ in xylene $(40 \mathrm{ml})$. After purification, the title compound $(1.44 \mathrm{~g}, 68 \%)$ was obtained as a yellow granular solid; m.p. $310{ }^{\circ} \mathrm{C} ; v_{\max }: 3308$ brs, 2947 brm, 2116 s, 1685 s, $1609 \mathrm{~m}, 1532$ s, 1503 s, $1441 \mathrm{~m}$, $1364 \mathrm{~s}, 1252 \mathrm{~m}, 1225 \mathrm{~m}, 1001 \mathrm{~s}, 806 \mathrm{~s}, 763 \mathrm{~s} \mathrm{~cm}^{-1}$; $\lambda_{\max }: 368 \mathrm{~nm}\left(\varepsilon\right.$ 11,695 cm-1 $\left.\mathrm{M}^{-1}\right), 350(13,568), 335$ (14,063), 237 (25,396), 196 (15,097); ${ }^{1} \mathrm{H}$ NMR (300 MHz, $\left.d_{6}-\mathrm{DMSO}\right): \delta 12.26(2 \mathrm{H}, \mathrm{s}, \mathrm{NH}), 8.24(2 \mathrm{H}, \mathrm{d}, J 8.2 \mathrm{~Hz}, \mathrm{H} 4 \mathrm{and}$ H9), $7.79(2 \mathrm{H}, \mathrm{d}, J 8.1 \mathrm{~Hz}, \mathrm{H} 5, \mathrm{H} 10), 7.67(2 \mathrm{H}, \mathrm{d}, J 2.3 \mathrm{~Hz}, \mathrm{H} 3, \mathrm{H} 8), 3.92\left(6 \mathrm{H}, \mathrm{s}, \mathrm{CO}_{2} \mathrm{Me}\right) ;{ }^{13} \mathrm{C} \mathrm{NMR}\left(d_{6}-\mathrm{DMSO}\right): \delta$ $162.08\left(\underline{C O}_{2} \mathrm{Me}\right), 134.69$ (aryl C), 125.94 (aryl C), $124.00(\mathrm{CH}=\underline{\mathrm{C}}), 123.18$ (aryl C), 121.88 (C4, C9), 113.79 (C5, C10), $107.27(\underline{\mathrm{CH}}=\mathrm{C}), 52.06\left(\mathrm{CO}_{2} \underline{\mathrm{Me}}\right) ; \mathrm{HRMS}\left({ }^{+} \mathrm{ESI}\right): \mathrm{C}_{18} \mathrm{H}_{13} \mathrm{~N}_{2} \mathrm{O}_{4}[\mathrm{M}-\mathrm{H}]^{+}$requires 321.0875, found 321.0866.

(1,6-Dihydroindolo[5,4-e]indole-2,7-diyl)dimethanol (23). The title compound was prepared as described for the general procedure 3 from dimethyl 1,6-dihydroindolo[5,4-e]indole-2,7-dicarboxylate (22) (1.00 g, 3.1 $\mathrm{mmol})$ and lithium aluminium hydride $(3.2 \mathrm{~g}, 168 \mathrm{mmol})$ in anhydrous tetrahydrofuran $(60 \mathrm{~mL})$. After filtration and purification, the title compound $(0.47 \mathrm{~g}, 57 \%)$ was obtained as a greenish granular solid;. m.p. $312{ }^{\circ} \mathrm{C} ; \mathrm{v}_{\max }$ : 3518 brs, 3259 brm, 1364 s, 1340 s, 1184 m, 1153 s, 1012 s, 979 s, 796 s, 768 s, 725 w, 521 w cm ${ }^{-1} ; \lambda_{\text {max }}: 368$ $\mathrm{nm}\left(\varepsilon 10,904 \mathrm{~cm}^{-1} \mathrm{M}^{-1}\right), 348(15,580), 334(16,495), 235(32,761) ;{ }^{1} \mathrm{H}$ NMR $\left(300 \mathrm{MHz}, d_{6}-\mathrm{DMSO}\right): \delta 11.18(2 \mathrm{H}, \mathrm{s}$, $\mathrm{NH}), 7.80(2 \mathrm{H}, \mathrm{d}, \mathrm{J} 8.6 \mathrm{~Hz}, \mathrm{H} 4, \mathrm{H} 9), 7.57(2 \mathrm{H}, \mathrm{d}, \mathrm{J} 8.7 \mathrm{~Hz}, \mathrm{H} 5, \mathrm{H} 10), 6.78(2 \mathrm{H}, \mathrm{d}, J 1.2 \mathrm{~Hz}, \mathrm{H} 3, \mathrm{H} 8), 4.69(4 \mathrm{H}, \mathrm{d}, J$ $\left.5.5 \mathrm{~Hz}, \underline{\mathrm{C}}_{2} \mathrm{OH}\right), 2.11\left(2 \mathrm{H}, \mathrm{bs}, \mathrm{CH}_{2} \underline{\mathrm{OH}}\right) ;{ }^{13} \mathrm{C} \mathrm{NMR}\left(d_{6}\right.$-DMSO): $\delta 138.32$ (aryl C), 131.77 (aryl C), $124.27(\mathrm{CH}=\underline{\mathrm{C}})$,

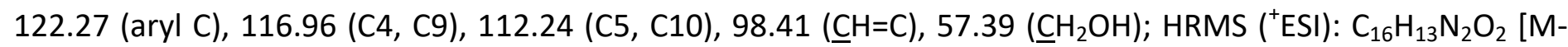
$\mathrm{H}]^{+}$requires 265.0977, found 265.0972 .

\section{Acknowledgements}

We thank the University of New South Wales and the Turkish Government for their financial support. 


\section{References}

1. Alley, M. C. Hollingshead, M. G.; Pacula-Cox, C. M.; Waud, W. R.; Hartley, J. A.; Howard, P. W.; Gregson, S. J.; Thurston, D. E.; Sausville, E. A. Cancer Res 2004, 64, 6700-6706.

https://doi.org/10.1158/0008-5472.CAN-03-2942

2. Kamal, A.; Rao, M. V.; Laxman, N.; Ramesh, G.; Reddy, G. S. K. Curr. Med. Chem. 2002, 2, 215-254. https://doi.org/10.2174/1568011023354119

3. Sengul, I.F.; Astarcl, E.; Kandemir, H., Synlett 2016, 27, 1277-1281. https://doi.org/10.1055/s-0035-1560601

4. Samsoniya, Sh. A. Trapaidze, M. V. Russian Chem Rev. 2007, 76(4), 313-326 https://doi.org/10.1070/RC2007v076n04ABEH003684

5. Boussard, M.-F.; Truche, S.; Rousseau-Rojas, A.; Briss, S.; Desamps, S.; Droual, M.; Wierzbicki, M.; Ferry, G.; Audinot, V.; Delagrange, P.; Boutin, J. A. Eur. J. Med. Chem. 2006, 41, 306-320.

https://doi.org/10.1016/i.ejmech.2005.12.002

6. Jin, Y.; Kim, K.; Song, S.; Kim, Ji.; Kim, Ja.; Park, S. H.; Lee, K.; Suh, H. Bull. Korean Chem. Soc. 2006, 27, 1043 https://doi.org/10.5012/bkcs.2006.27.7.1043

7. Gil, M.; Marczyk, J.; Dobrin, S.; Kaszynski, P.; Waluk, J. J. Mol. Struct. 1999,475, 141 https://doi.org/10.1016/S0022-2860(98)00499-2

8. Dobrin, S.; Starukhin, A.; Kaszynski, P.; Valuk, Y. Opt. Spektrosk. 1997, 83, 669

9. Dobrin, S.; Kaszynski, P.; Ikeda, S.; Waluk, J. Chem. Phys. 1997, 216, 179 https://doi.org/10.1016/S0301-0104(97)00018-9

10. Dobrin, S.; Kaszynski, P.; Waluk, J. J. Photochem. Photobiol. A 1997, 105, 149 https://doi.org/10.1016/S1010-6030(96)04609-6.

11. Golubeva, P. Zh. Rus. Fiz.-Khim. O-va 1884, 16, 577, Golubew, P. Berichte 1884, 17c 581

12. Kliegl, A.; Haas, K. Berichte, 1911, 44, 1209 https://doi.org/10.1002/cber.19110440206

13. Martinet, J.; Vacher, F. Bull. Soc. Chim. Fr. 1922, 31, 435

14. Soloducho, J. Tetrahedron Lett. 1999, 40, 2429 https://doi.org/10.1016/S0040-4039(99)00121-5

15. Kolesnikov, A. M.; Mikhailenko, F. A. Zh. Org. Khim. 1982, 18, 441

16. Samsoniya, Sh. A.; Trapaidze, M. V.; Gverdtsiteli, I. M.; Suvorov, N. N. Khim. Geterotsikl. Soedin. 1977, 1279

17. Samsoniya, Sh. A.; Trapaidze, M. V.; Suvorov, N. N.; Gverdtsiteli, I. M. Soobshch. Akad. Nauk Gruz. SSR 1978, 91361

18. Samsoniya, Sh. A.; Trapaidze, M. V.; Dolidze, S. V.; Esakiya, N. A.; Suvorov, N. N.; Kolesnikov, A. M.; Mikhailenko, F. A. Khim. Geterotsikl. Soedin. 1984, 352

19. Hemetsberger, H.; Knittel, D.; Weidmann, H. Monaths Chem. 1970, 101, 161-165. https://doi.org/10.1007/BF00907536

20. Hemetsberger, H.; Knittel, D.; Weidmann, H. Monaths. Chem. 1969, 100, 1599-1603. https://doi.org/10.1007/BF00900176

21. Bolton, R. E.; Moody, C. J.; Rees, C. W.; Tojo, G. J. Chem. Soc. Perkin Trans. 1 1987, 931-935. https://doi.org/10.1039/P19870000931

22. Hardy, G. W.; Bull, D.; Jones, H. T.; Mills, G.; Allan, G. Tetrahedron Lett. 1988, 29, 799-802. https://doi.org/10.1016/S0040-4039(00)80213-0 
23. Miyaji, T.; Azuma, C.; Asaoka, E.; Nakamura, S., J. Polym. Sci. 2000, 38, 1064-1072. https://doi.org/10.1002/(SICI)1099-0518(20000401)38:7<1064::AID-POLA3>3.0.CO;2-2

24. Boger, D. L.; Santillan, A.; Searcey, M.; Jin, Q. J. Am. Chem. Soc. 1998, 120, 11554-11557. https://doi.org/10.1021/ja9818093

25. Harrison, C. A.; Leineweber, R.; Moody, C. J.; Williams, J. M. J. The Royal Society of Chemistry: Cambridge, UK, 1995.

26. Cotterill, A. S.; Hartopp, P.; Jones, G. B.; Moody, C. J.; Norton, C. L.; O'Sullivan, N.; Swann, E. Tetrahedron 1994, 50, 7657-7674.

https://doi.org/10.1016/S0040-4020(01)90492-2

27. Vilsmeier, A.; Haack, A. Ber. Dtsch. Chem. Ges. 1927, 60, 119.

https://doi.org/10.1002/cber.19270600118

28. Wang, M.-L.; Lee, Z.-F.; Wang, F.-S. J. Mol. Catal. A-Chem. 2005, 229, 259-269.

https://doi.org/10.1016/j.molcata.2004.11.027

29. Klanderman, B. H. J. Org. Chem. 1966, 31, 2618-2620.

https://doi.org/10.1021/jo01346a038

30. Samsoniya, S. A.; Trapaidze, M. V.; Dolidze, S. V.; Ésakiya, N. A.; Suvorov, N. N.; Kolesnikov, A. M.;

Mikhailenko, F. A. Chem. Heterocycl. Comp. 1984, 20, 283-288.

https://doi.org/0009-3122/84/2003-0283508.50 